\title{
Inclusive Education Between Humanistic Idea and Corporative Model of Education: Are the Special Schools Better?
}

\author{
Haris Cerić \\ Prof. dr. Faculty of Political Sciences, University of Sarajevo
}

Amel Alić

Prof. dr. Faculty of Philosophy, University of Zenica

\begin{abstract}
In this paper a paradox of global educational politics is problematized (GERM - global education movement) that is reflected in education reforms of numerous countries as it is insisted on uncompromizing introduction of inclusive education, while at the same time, more and more bigger breakthrough of neoliberalism is evident in education. Neoliberal education, that is corporative model of education, based on marketing orientation and imposing the demands for higher academic standards in order schools to be more competitive, is contradictory to humanistic and egalitarian idea of inclusion in education with the final aim of improvement of inclusive education in which all children, young and adults no matter of differencies, are given an opportunity to take part in and to give their own contribution. In practice, it is also questioned the co-existence of inclusive education and corporative model of education along with presenting the reflections and researches of some authors who emphazise the advantages of special education.
\end{abstract}

Keywords: inclusive education, neoliberal education, corporative model of education, special schools, researches of inclusive education

\section{Introduction}

Philosophy of inclusive education is that all children have right to be educated together with their peers in regular classes in schools that are the closest to their place of residence. It is necessary to differ the determination of inclusive education both in broad and narrow sense. Inclusive education being understood in wider sense is related to strategies of inclusion into regular educational system of all the children that due to some of their characteristics (age, sex, abilities, race, ethnic and religious membership, health status etc.) are being exposed to different kinds of marginalization, segregation, isolation and discrimination as in school so in society in general. In narrow sense, inclusive education is related in including the children having disability-related differences (disorders with eyesight, hearing, talking, mental insufficiency, behavioral disorders, multiple disorders) into regular schools. Our intention is to problematize the paradox of global educational politics (GERM - global education reform movement) reflecting in the fact that in educational reforms of numerous countries it is insisted on uncompromising introduction of inclusive education but at the same time, a breakthrough of neoliberalism in educationn is more and more evident. Neoliberalism in 
education is characterized by procedures such as evaluation, clasification, quantification, acreditation standardized tests, evaluation criteria and orientation toward perfection that is manifested in shape of increased competition among schools. As Tolofari (2005) has noted, education becomes a product at the market which should be more effective and efficient, students become buyers of services, but supply and demand are determined by market mechanisms, that is neoliberals want competition, choice, efficiency and accountability.

\section{Inclusive Education vs Corporative Model of Education}

In that regard, some authors (Hardy and Woodcock, 2015; Kreitz-Sadberg,2015; Skrtic, 2009; Slee, 2011) consider as neoliberal market orientation and individualised view upon society imposing bigger demands in respect to academic standards in order schools to be more competitive, are contradictor to the idea of inclusion in education. According to Stubbs (2008) inclusive education refers to a wide range of srategies, activities and processes that seek to make a reality of the universal right to equality, relevant and appropriate education where all differences according to age, gender, ethnicity, language, health status, economic status, religion, disability, life-style and other forms of difference are acknowledged and respected. Therefore, inclusive education represents a humanistic idea whose final aim is the improvement of inclusive society enabling to all children, young and adults regardless of differences to take part and contribute in it. Of course, such understanding of society does not imply the balance - does not mean as all the members of society are equal ones, but all regardless to afore mentioned differences have equal right to possibility to take part in and to belong to the society, that is to educate in accordance with their abilities. Such understanding of "equality“ contributes to eradication and decreasing of the all forms of seggregation, separation, isolation and discrimination.

On the other side, instead to be engaged in strenghtening up the neccessary diversity being understood under the concept of inclusive education, neoliberal ideology suggests a revival of one-dimensional interpretation of school based on individualism, competitiveness, social darvinism, talent myth and similar, that leads to marketing of education, that is abolishing the education as basic human right and common good. As Liasidou mentioned, „the values of the marketplace are enshrined in educational institutions, which are called upon to produce 'human resources' in order o fulfil the demands of the global economy, thereby relating to the margins those students who are allegedly deemed 'unfit' to meet the demands of corporate modes of schooling (e.g. disabled students)“ (Liasidou, 2015:8). So, neoliberal educational trends represent an attack on egalitaristic norms, social equlity, right to possibility all to take part in and belong to the society, therefore to be educated in accordance with their abilities that represents the essence of inclusive education concept.

Apple (2001) perfectly detects the key elements of corporative educational mode where the education is mainly based on transfering the neutral knowledge on the students but the basic role of school is „to fill in“ the students with knowledge needed for taking part in fast changing world. The executive arbiter in evaluation of transfer and knowledge acquisition are tests of acquisition intended to state the educational level as „objectively“ as possible. If everything functions well, „good“ students will finally „learn well“, gain good results, take good positions and work on good jobs in society and to earn much more money. This effectiveness line is followed by financial benefit of schools and school systems in charge of knowledge transfer and preparation of "good“ experts. Newly ethroned centers of power have inviolable right to define „the history of real culture“ and „real knowledge“ (Apple, 2001:9). This contruction of 
good schooling, good management and good results in final, has been traced by those social powers that gained a domination in society aiming to increase the profit and their own positions, finding decisively important interest in education. Apple recognizes four key interest groups having a monopoly over education in The United States of America, and they more and more impose to the rest of the world the ideal of "good“ and „real“ knowledge, the adequate method of revising of the „functionality“of acquired knowledge strongly influencing the „peripheral“ cultures to re-shape and continually come closer to the ideal knowledge core of global culture. Apple recognizes those social powers through the impact of neoliberals, neoconservatives, aggresive populists and technomanagers.

Corporative educational model based upon neoliberal economic ideas is characterized by the values of market to be applied onto educational institutions where the value of student is reflected in how much is able to contribute to the labor market, that is „students have been increasingly viewed as profitmaximazing pawns in the service of an 'audit culture', whereby a school's 'effectiveness' is measured against simplistic and superficial assesment procedures akin to corporate rationality" (Liasidou, 2015:11). As a rule, students that are not able to adjust themselves into corporative educational model are those originating from ethnic minorities, poor students, as well as those having various disabilities. Therefore, all those students included in inclusive education concept. Along with all previously said, a question is imposing whether the concept of inclusive education (especially its narrow understanding), has any sense in those educational systems where neoliberal ideas dominate?

The idea of inclusive education which is utterly human and has its scientific-theorethical basis and justification (e.g. Allport's contact hypothesis ${ }^{1}$, Vygotsky's zone of proximal development ${ }^{2}$ and similar) is sensless to a good extent in corporative educational model that is based upon competitiveness and oriented to prefection, so it is questionable whether including a child, at any cost, having some disability into regular school be of any advantage for it. Kaufman (1989) for example, considers as a try all these students to be included into regular education is equally forcedly and discriminating as it would try to include the all students into special classes and special institutions. At the same time, it should bear in mind that there are categories of children which, along with the best conditions and support can not be included into regular education. Advantages of special schools for education of some categories of children with disabilities in regard to inclusive schools a famous philosopher Mary Warnock in the introduction of the book Celebrating the Special School gives the following arguments:

I profoundly believe that for many children, not only those with the most severe or multiple disabilities, special schools are their salvation. They can trust their teachers to understand their difficulties and they can be free from the teasing and bullying that they fear from their fellow students (and this fear is more intense for those children who are not visibly or obviously disabled, such as those with autism in its various degrees). One of the huge

\footnotetext{
${ }^{1}$ The concept of inclusive education, especially its socialization and non-academic aspects, is based on the contact hypothesis. According to the contact hypothesis, the general student population is expected to reduce prejudice, ie to form positive attitudes, to accept diversity and to build friendships through repeated contact / exposure to children with disabilities (Cerić, 2019).

2 Vygotsky's consideration of „zone of proximal development“ and his understanding of disabilities from socio-cultural aspect could be accepted as theoretical starting point of inclusive education. The conception of „zone of proximal development" enables individualization of learning process and explains positive influence of social environment on development, upon demand of inclusive education disciples for educating heterogeneous groups of students in regular schools is based. Making distinctly shift from biological to socio-cultural explanation of disabilities, Vygotsky anticipated today's broadly accepted social model, which is in the basics of inclusive education, according to its barriers to learning and participation arise through an interaction between students and their context; the people, policies, institutions, cultures, and social and economic circumstances that affect their lives (Cerić and Alić, 2005).
} 
advantages of a special school for such children is that it is small. In a small school, a child knows everyone and is known by all the staff. The staff, too, know one another and work in a collegiate atmosphere, where they can share their insights and their problems. Special schools are, of course, not cheap. But the policy of inclusion in mainstream schools should not be cheap either if it is to provide enough support for individual students to enable them to flourish. It is not enough that children with special needs in mainstream schools should be supported by teaching assistants; they need expert, trained teachers, who can teach them in small groups, or one-to-one. This is something that few mainstream schools can offer. What has been wrong with the policy of inclusion has been the idea that if some children with special needs can flourish in the mainstream they all can (2006: viii-ix).

Furthermore, the inclusive schools imply considerable investment into education of teachers working with children having disabilities and creating the adequate conditions for their work, as well as school infrastructure and resources (teaching aids and apparatus, adjusted access to school, space and material conditions and similar. Apple picturesquely talks about it:

While in an ideal situation I would prefer to have inclusive schools, on the other hand, in the realities of too many classrooms what we have now are rising class sizes, decreasing budgets, more social problems in the schools, and the intensification of teachers' labor. To quote from one of my friends who teaches in the schools of my own city, 'Michael, I don't have time even to go to the bathroom during the day.' Given this kind of situation, what is happening in many ways to teachers is that the rethoric is saying "inclusion," but the reality says 'Dump these children into a regular classroom, and give no help, no assistance, no resources to teachers who are already in conditions that make life extremely difficult.' Hence, in the real situation in a considerable number of schools and classrooms, what we have is often equivalent to what we did when we closed mental hospitals in the United States. We dumped people back into the communities and let them sink or swim, with little long-term support. And by and large, they sank (Apple, 2004: 200).

Palmer et al (2001) analyzed the written comments of 140 parents of students having serious disabilities in order to establish the reasons why do they support or are against the curriculum of inclusive education. Reasons for parents' support are assurances as their children would learn more in regular classrooms. Parents opposing the inclusion mostly thought as the seriousness of disabilities of their children prevent any kind of benefits from such curriculum, therefore, inclusive classrooms would not be appropriate for education of their children.

Gilmour (2018) considers that researches, unfortunatelly, gave just weak evidences as educational inclusion brings benefits to students with disabilities, and that studies reporting on better academic results and sociability outcomes for students with disabilities being taught at regular schools, suffer from lack of methodology. Less evidences suggest that the teachers of regular schools are adequately prepared to meet unique academic and social needs of disabled students. One of crucial methodology lack in research of inclusive education is that they are mostly based on presumption as students with diabilities are educated in a vacuum; i.e. they are mostly focused on effectiveness gained at students with disabilities while the impact of educational inclusion on typical fellow students and teachers is ignored. Mutual interaction between teachers and students with disabilities from general population is exactly imposed as the research field whose results could direct a future discussion on inclusive education and improve school inclusive practice. 
The fact that disabled students included into regular classrooms fall behind their typical fellow students, and that their mere placement into inclusive classrooms does not improve their academic achievements is confirmed by results of meta-analyses of 23 studies conducted by Gilmour et al (2018). Namely, they established that in regard to reading ability at students with disabilities there is standard deviation about 1.17 in relation to typical fellow students which represents a falling behind during more than three years in academic improvement.

The research conducted by Siperstein et al (2007) shows that including children with intellectual disabilities could increase negative attitudes toward them in general students' population. The authors of this study polled random sample comprising of 5837 students of secondary schools on national level about their attitudes to including their fellow students with intellectual disabilities into regular schools. The findings show that students: (a) have limited contact with students with ID in their classrooms and school; (b) perceive students with ID as moderately impaired rather than mildly impaired; (c) believe that students with ID can participate in nonacademic classes, but not in academic classes; (d) view inclusion as having both positive and negative effects; and (e) do not want to interact socially with a peer with ID, particularly outside school. The key findings gained by Hardiman et al (2008) , comparing social competences of children with mild intellectual disabilities in inclusive contrary to segregated school enviroments, show that children in inclusive schools do not significantly differ from children at segregated scools in regard to social competences which support a presumption that children having intellectual disabilities can function well in various educational environments.

\section{Conclusion}

The concept of global education policy has appeared over the last few decades, and it is about phenomenon that implicates the characteristics of educational reform present at the global level (GERM). The methapors "marketing meta-governance" (Woods, 2011) and "Westernized version of educational modernization" (Alić, 2018) refer to undertaking educational reforms in the US, UK and other Western-centric socio-political systems, based on neoliberal ideologies, whose fundamental goal is to restructure education so that it begins to contribute to economic growth and development. Such an understanding of education that rests on the demand for competiveness, profitability and increased productivity is at odds with the concept of inclusive education based on concerns about human rights, social justice, collegiality and the common good. Neoliberal versions of inclusion are harmonized with the standards agenda supported by the ascendancy of market-based imperatives (Dyson, 2005).

And finally, our ultimate question might be: is there any possibility to accomplish the idea of inclusive education in predominantly market and neoliberally oriented world?

One, among, not so many positive examples exists in Finland, which have somehow avoided neoliberal directions, and maintained a strong focus on a social democratic vision in education policy and practice, have managed to achieve higher educational standards and more equitable educational outcomes for learner diversity (Hargreaves and Shirley 2012; after Liasidou, 2015:10). While explaining the nature of Finnish educational reforms, Sahlberg (2010, after Liasidou, 2015:10) points to the fact that the country has not been influenced by the global education reform movement (GERM), which has emerged from the interests of supranational development agencies and has been geared towards introducing high-stakes accountability regimes for schools. 
Having in mind a positive Finnish example, a resistance to market-oriented educational system is possible exclusively in a case of entire social emancipation directed to the ideal of social justice. Such concept enables the equal possibilities to all students, egalitarian distribution of all resources, minimizing the effects of competition among students, gradual building up of a higher level of confidence among the all participants within educational system especially among teachers, parents and students. Such approach, besides the social model, directs much more to some key standpoints of spiritual-scientific pedadogy, that is still considered to be remote, idealistic and humanistic point of view onto education (Alić, Cerić and Habibović, 2018). Finally, within a tradition of spiritual-scientific pedagogy is said: The aim of bringing up is education as a subjective way of culture existence, but not achieving the skilled qualification, so, it brings to conclusion as education is spiritual achievement, inner accomplishment, the state of soul, higher life, „ethos“ of living area, a credential into timeless values...(König and Zedler, 2001).

Meanwhile, such huanistic ideal is totally opposed to neoliberal, competitive, corporative models of education. If, by market logic, a gap between „typical“ and students with disabilities deepened, in that case it perhaps better following the traces of Mary Warnock's thoughts as well as numerous researches on effectiveness of inclusive education, to save the children with disabilities from additional stigmatizing and to improve the work of special schools?

\section{References}

[1] Alić, A., Cerić, H., and Habibović, S. (2018). The rulers of "No man's land": study of cultural contact and social impact of the United World College of Mostar. Sarajevo: Dobra knjiga.

[2] Alić, A. (2018). Kulturalni modeli odgajanja - uvod u antropologiju porodice. Sarajevo: Perfecta.

[3] Alić, A., Cerić, H., and Habibović, S. (2017). Evaluations of Students and Teachers on Quality of Teaching Process Regarding Working Styles. European Journal of Social Science Education and Research, 4(4), 94-100.

[4] Apple, W.M. (2001). Educating the Right Way: Markets, Standards, God, and Inequality. New York: Routledge Falmer.

[5] Apple, M. W. (2004). Ideology and curriculum. Routledge.

[6] Cerić, H. (2019). Postaje li inkluzivno obrazovanje ideologija suvremenog obrazovanja? Sarajevo Social Science Review, Vol.1-2:7-19.

[7] Cerić, H., Alić, A. (2005). Temeljna polazišta inkluzivnog obrazovanja. Zenica: Hijatus.

[8] Dyson, A. (2005). 'Philosophy, politics and economics? The story of inclusive education in England'. In Mitchell, D. (Ed.) Contextualising Inclusive Education: Evaluating Old and New International Perspectives. London: Routledge, 63-88.

[9] Gilmour, A. F. (2018). Has inclusion gone too far? Weighing its effects on students with disabilities, their peers, and teachers. Education Next, 18(4), 8-17.

[10] Hardy, I., and Woodcock, S. (2015) "Inclusive Education Policies: Discourses of Difference, Diversity and Deficit." International Journal of Inclusive Education, 19 (2): 141-164

[11] König, E. and Zedler, P. (2001). Teorije znanosti o odgoju. Zagreb: Educa.

[12] Kreitz-Sandberg, S. (2015.) "As an Educator You Have to Fix Many Things on Your Own. Teachers Perspectives on Organizing Inclusions in Various Welfare Contexts." In: Rights of Children in the Nordic Welfare States, edited by G. H.Jacobsen, 145-167. Copenhagen: NSU Press. 
[13] Liasidou, A. (2015). Inclusive education and the issue of change: Theory, policy and pedagogy. Springer.

[14] Palmer, D. S., Fuller, K., Arora, T., \& Nelson, M. (2001). Taking sides: Parent views on inclusion for their children with severe disabilities. Exceptional children, 67(4), 467484.

[15] Skrtic, T.M. (2009). Reflection - Tom Skrtic. In Taking Stock of Special Education, Policy \& Practice: A Retrospective Commentary. Edited by Skrtic, T. M., Horn, E. M., \& Clark, G. M., 421-422. Denver: Love Publishing Company.

[16] Slee, R. (2011). The irregular school: Exclusion, schooling and inclusive education. Routledge.

[17] Siperstein, G. N., Parker, R. C., Bardon, J. N., \& Widaman, K. F. (2007). A national study of youth attitudes toward the inclusion of students with intellectual disabilities. Exceptional children, 73(4), 435-455.

[18] Stubbs, S. (2008). Inclusive Education: Where There Are Few Resources, Atlas Alliance, Norway.

[19] Tolofari, S. (2005). New public management and education. Policy futures in education, 3(1), 75-89.

[20] Warnock, M. (2006). Foreward. In: Farrell, M. (2006). Celebrating the special school. David Fulton Publishers.

[21] Woods, P. (2011). Transforming Education Policy: Shaping a Democratic Future. Bristol: Policy Press. 